\title{
Agriculture Insurance's Outreach Constrained by Procedural Delays and Norms: Reflections from North Karnataka, India ${ }^{1}$
}

\author{
Nayanatara S. Nayak ${ }^{1 *(2)}$ Narayan Billava $^{2(3)}$ Ashalata K.V. $^{3(4)}$ \\ 1. Centre for Multi-Disciplinary Development Research (CMDR), Y.S. Colony Dharwad, Karnataka, India \\ 2. CMDR, Dharwad, Karnataka, India \\ 3. Department of Statistics, University of Agricultural Science (UAS), Dharwad, Karnataka, India
}

\begin{tabular}{|c|c|}
\hline ARTICLE INFO & ABSTRACT \\
\hline $\begin{array}{l}\text { Article history } \\
\text { Received: } 1 \text { December } 2020 \\
\text { Revised: } 7 \text { December } 2020 \\
\text { Accepted: } 8 \text { December } 2020 \\
\text { Published Online: } 30 \text { December } 2020 \\
\text { Keywords: } \\
\text { Crop insurance } \\
\text { Pradhan Mantri Fasal Bima Yojana } \\
\text { Agriculture Insurance } \\
\text { Farmers } \\
\text { Claims }\end{array}$ & 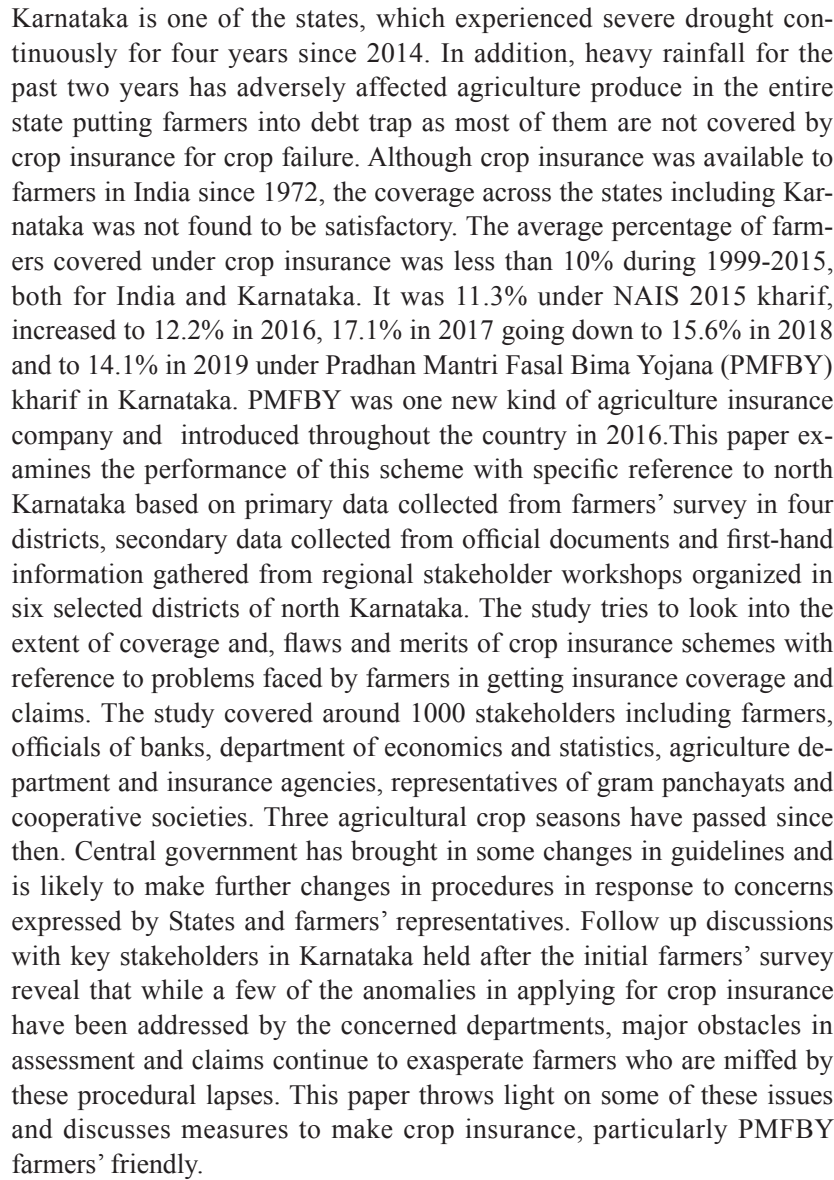 \\
\hline
\end{tabular}

\footnotetext{
*Corresponding Author:

Nayanatara S. Nayak,

Centre for Multi-Disciplinary Development Research (CMDR), Y.S. Colony Dharwad, Karnataka, India; Email:nsn.cmdr@gmail.com
}

(1) This paper is based on the study sponsored by KAPC, Bengaluru and carried out by CMDR, Dharwad during $2016-17$.

(2) Professor, Centre for Multi-Disciplinary Development Research (CMDR), Y.S. Colony Dharwad, Karnataka, India. Email.id: nsn.cmdr@gmail.com

(3) Assistant Professor, ANS Chair, CMDR, Dharwad, Karnataka, India. Email.id: n.billava@gmail.com, Phone: 9740467379

(4) Professor, Department of Statistics, University of Agricultural Science (UAS), Dharwad, Karnataka, India 


\section{Introduction}

$\mathrm{K}$

arnataka is one of the states, which experienced severe drought continuously for three years since 2014. And for the past 2 years the state is facing huge losses due to heavy rainfall, which has adversely affected agriculture produce in the entire state including economic losses to the state economy. The climate change leading to frequent fluctuations in weather conditions has cast an evil spell on agriculture compelling the government and farmers to look out for insurance against crop loss. Although crop insurance is available to farmers in India since 1972, the coverage across the states including Karnataka is not satisfactory. Several studies and the report of $\mathrm{CAG}^{[1]}$ indicate poor performance of crop insurance schemes in India and, the issues identified are similar, persistent and appear to have existed from the beginning of the implementation of the schemes. Lack of awareness, focusing only on loanee farmers, availability of insurance for a few crops, meager claim amount, delayed claims and corrupt practices were the main reasons quoted by studies for low preference for crop insurance among farmers. The situation is not different in Karnataka.

Previous governments at the centre tried and experimented with 11 crop insurance schemes during 1972 to 2015 the last being National Crop Insurance Scheme (NAIS). But, none of the schemes seemed to be comprehensive and, failed to attract large number of farmers. On an average, the coverage of farmers under crop insurance was less than 10\% in India during 1999-2015. In this background, 3 new schemes viz. Restructured Weather Based Crop Insurance Scheme (RWBCIS), Pradhan Mantri Fasal Bima Yojana (PMFBY) and Unified Package Insurance Scheme (UPIS) were introduced in the country in 2016. In addition to these three new/restructured schemes, the central government retained Coconut Palm Insurance Scheme (CPIS). PMFBY has been hailed as farmer friendly with provision for cap on farmers' share in premium, submission of online applications, increase in sum insured, direct transfer of claims to farmers' accounts, coverage of large number of crops, lower premium rates as compared to the provisions in earlier schemes, etc. But, how does the scheme score in actual implementation? And, what are the responses of different stakeholders including farmers? This paper tries to address these issues by looking into ground level realities through field visits, household survey and, by interacting with different stakeholders in selected districts of north Karnataka.
The paper is based on an empirical study ${ }^{\mathbb{1}}$ carried out during 2016-2017. The discussion is presented in six sections. The introduction is followed by a brief review of crop insurance, research methods, status of crop insurance in Karnataka focusing on PMFBY including their coverage and performance, performance of NAIS-2015 versus KRSPMFBY-2016 and stakeholder perceptions on PMFBY. The last section presents summary and conclusions.

\section{Crop Insurance in India - A brief Review}

Crop insurance is available to farmers in India since 1972 in different forms and capacities. And many researchers and organizations have tried to evaluate crop insurance schemes over time across India. There is also a great volume of information available on crop insurance in Karnataka.

In the words of Ifft ${ }^{[2]}$. "Government crop insurance has proved to be a failure worldwide, but India seems to have ignored both its own failure and the failure of other countries." Several other studies also support this view. A study on CPIS in Kerala on banana insurance revealed that the scheme was not financially viable as it caused a heavy burden to the government and, farmers were found getting enrolment in the scheme only when they actually faced a threat of damage and the claim was submitted within a week of enrolment ${ }^{[3]}$. An evaluation of the crop insurance programme in India routed through NAIS, which existed till 2014-15 reveals that "while NAIS has done well on equity grounds, the coverage and indemnity payments were biased towards a few regions and crops, and there were delays in settlement of claims" ${ }^{[4]}$. A Study carried out in Krishna district of Andhra Pradesh ${ }^{[5]}$ reveals that crop insurance is viewed as beneficial to large farmers and its extent in risk sharing was found to be very low. The Joint Group ${ }^{[6]}$ constituted by Government of India to review crop insurance had recommended compulsory coverage of personal accident, medical and insurance for "dwelling and contents" along with crop insurance and, provision of subsidized crop insurance, premium capping, etc. According to a study by Banerjee and Bhattacharya ${ }^{[7]}$ agriculture insurance in India is still at experimental and developmental phase. They point out the gap between insurance providers and receivers and opine lack of awareness among farmers and compulsion to include loanee farmers as setback for the programmes.

Swain ${ }^{[8]}$ studied NAIS and WBCIS schemes in Odisha using secondary time series data from 2000-2010 ${ }^{[7]}$ and, information gathered through focused group discussion

(1) This study was sponsored by Karnataka Agriculture Price Commission, Government of Karnataka, Bengaluru 
with insurance users and found that WBCIS performed better than NAIS because of higher coverage, lower premium, faster and higher frequency of compensation payment though the sum assured and the compensation amount were lower. While NAIS farmers did not receive any indemnity during past 8 years of the study, most of the WBCIS farmers received compensation twice during the period. The Report of the Committee of Department of Agriculture and Cooperation ${ }^{[9]}$ highlights the failed attempts to implement crop insurance schemes in India over the past five decades. And many of the issues and problems highlighted when the Committee interacted with stakeholders appeared to be chronic and existed since implementation of crop insurance schemes in the country and remained unaddressed. $\mathrm{CSE}^{[10]}$ carried out a study on the performance of PMFBY in kharif 2016 based on the field visits in 3 states viz. Haryana, Tamil Nadu and Uttar Pradesh, personal interviews with stakeholders and a round table discussion with farmer leaders and civil society members from 8 states. The study reveals increase in the area insured (18\%), increase in sum insured per hectare of land (by $68 \%$ ) and increase in number of farmers $(30 \%)$ insured both, loanee and non-loanee as compared to the performance under previous scheme (NAIS). The study states that although PMFBY is a transformative scheme with improvement over previous schemes, it has failed to reach out to farmers due to challenges in implementation that are listed as delayed notification, delay in payment of state government subsidies, low coverage of tenant and sharecroppers, lack of involvement of panchayat institutions, poor awareness about the scheme, poor coordination between implementing officials, absence of acknowledgment for purchase of insurance, double deduction of premiums, wrong entries, loopholes in conducting CCEs, high actuarial premium rates and delay in claim settlement. Dey and Maitra ${ }^{[11]}$ Studied the performance of PMFBY and WBCIS in terms of its coverage of farmers, crops, premium rates and claim payout efficacy across states in India based on secondary information. The findings of the study suggest that while efficient claim payout may increase beneficiary coverage under PMFBY, subsidy and actuarial premium rates will have impact on coverage under WBCIS. The latest ${ }^{[1]}$ presents a performance audit of crop insurance schemes implemented in India during 2011 to 2015-16, i.e. before implementation of PMFBY. The report highlights that the governments have failed to buildup database of farmers over the years, failed to increase coverage and awareness.

Studies on evaluation of earlier crop insurance schemes in Karnataka speak about low coverage of farmers and area although Karnataka ranks eighth in terms of farmer coverage under crop insurance according to cumulative statistics ${ }^{[12]}$ available for the period 1999-2015 covering both kharif and rabi seasons. Kalavakonda and Mahul ${ }^{[13]}$ find crop insurance schemes in Karnataka to be performing poorly in terms of area coverage, farmer enrolment and, financial performance. A study on crop insurance in Karnataka by ${ }^{[14],}$ based both on a sample survey of farmers in Mandya, Chamrajnagar and Haveri districts in Karnataka and an analysis of NSSO $59^{\text {th }}$ round ${ }^{[15]}$ reveals that farmer households with higher levels of education, economic status and social class are likely to adopt crop insurance.

Rampant fraudulent practices were noticed in the past in states like Karnataka, Gujarat, Andhra Pradesh, Maharashtra, with network of farmers, bank officials and agriculture department officials accused of running rackets for generating false insurance claims and usurp money ${ }^{[16]}$ A study by Goudappa et al ${ }^{[17]}$ covering the farmers who purchased NAIS in the districts of Hyderabad-Karnataka region reveals that farmers were not aware of crop insurance schemes and farmers were not happy with the implementation of the scheme by the agriculture department.

CAG report and, studies carried out by individuals and various agencies in nut shell indicate poor performance of crop insurance schemes in India and, the issues identified are similar and appear to be existing from the beginning. But there has not been serious effort to take concrete action to address these loopholes overtime. However, reviews of the provisions of PMFBY indicate that most of the recommendations of the Joint Group ${ }^{[6]}$ and Mishra Committee ${ }^{[9]}$ seem to have been considered and included under PMFBY, which is a welcome feature.

\section{Methods}

The focus of this study was on 2016 kharif season with specific reference to north Karnataka. The study relied on two major primary sources to get the relevant field level information, which included a sample survey of 120 farm households in four selected districts of north Karnataka viz, Belgaum, Haveri, Kalaburgi and Raichur carried out during September-November 2016 and the villages selected respectively being Maladinni, Devihosur, Hagaraga and Mittimalakapur and, seven regional workshops organized for about 600 farmers and other stakeholders in Belgaum, Dharwad, Haveri, Kalaburgi, Raichur and Vijayapura of north Karnataka. In addition, information was gathered through informal discussions with around 400 farmers, relevant department officials and insurance agency representatives. State level information on coverage, premium collection and sum insured was collected from agriculture departments and insurance agencies (IAs). 


\section{Performance of PMFBY in Karnataka}

Currently four agriculture insurance schemes including PMFBY (renamed as Karnataka Raita Suraksha Pradhan Mantri Fasal Bima Yojana (KRSPMFBY), Restructured Weather Based Insurance Scheme (RWBCIS), Coconut Palm Insurance Scheme (CPIS) and, Unified Package Insurance Scheme (UPIS) implemented on pilot basis in Belgaum and Chitradurga districts are operative in Karnataka. UPIS implemented on pilot basis in 45 districts of India and 2 districts of Karnataka includes PMFBY as one of its seven components. In this paper the discussion is focused on PMFBY 2016 kharif for which claim details are available. In comparison specific references are made to NAIS kharif 2015.

PMFBY has been renamed as Karnataka Raita Surakasha Pradhan Mantri Fasal Bima Yojana (KRSPMFBY) in Karnataka. It is an all India multi- peril insurance scheme covering non-preventable risks including prevented sowing/planting risks, loss to standing crop, post-harvest losses (up to 2 weeks) and localized calamities. Premium payable by farmers is $2 \%$ for kharif crops, $1.5 \%$ for rabi crops and $5 \%$ for annual commercial and horticultural crops or actuarial rate, whichever is less. It follows yieldbased area approach, which earlier was compulsory for loanee farmers and voluntary for non-loanee farmers with provision for covering tenants and sharecroppers also. For claim settlement, crop loss estimated by agriculture department based on yield data obtained through crop cutting experiments (CCEs) is forwarded to IAs for claim settlement. Insurance Unit is village/village panchayat for major crops and Hobli/Taluk for other crops. IAs quoting lowest bid are selected in open bidding arranged by the state government. PMFBY does not cover risks due to theft, malicious damage, act of enmity, crop damage by domestic/wild animals and provides toll-free number for grievance redressal.

The recent changes ${ }^{(\mathbb{1}}$ made in PMFBY guidelines include making insurance optional to farmers, capping on central subsidy at $30 \%$, allowing insurance companies to tender for 3 years, adopting two-step process for estimation of crop losses based on a defined deviation matrix from normal using triggers such as weather or satellite indicators. Some of these guidelines apply to RWBCIS also. Other modifications include conducting CCEs in areas only with strong deviations reflected through remote sensing for the assessment of yield loss, giving option to states to choose scale of finance (earlier the sum insured was the same for both loanee and non-loanee and was equal to

(1) Pib.gov.in 'Cabinet approves revamping of Pradhan Mantri Fasal $\cdots$ PIB, February 19,2020 . scale of finance), preventing states which delay payment of premium subsidy to insurance companies from participating in PMFBY, with cut off dates for invoking this provision being $31^{\text {st }}$ March for kharif and $30^{\text {th }}$ September for rabi seasons, use of smart sampling technique for CCEs and optimization of number of CCEs, settlement of claims based on yield arrived through use of technology in case of non-provision of yield data beyond cut-off date by the States to insurance companies. Further, the Government of Karnataka has set up "Farmers" Crop Survey App 2020$21^{\prime}$ to enable farmers to upload crop images and details through mobile. This will help in bringing about transparency and prevent delays in claims due to defaulting by farmers as they themselves send crop details.

Karnataka has smoothened crop insurance system in the state by developing Samrakshane (meaning protection) Web Portal designed and uploaded with the help of National Informatics Centre (NIC), Bengaluru. The website provides link to terms and conditions of schemes, notified crops, premium rates, cut off dates, company details, insurance premium calculator, and facilitates banks to upload applications online. Samrakshane website links Bhoomi (land record) to bank accounts of farmers. The status of the crop is assessed by agriculture/revenue/Rural Development and Panchayati Raj (RDPR)/Directorate of Economics and Statistics (DES) staff through Global Positioning System (GPS) tracked mobile app attached to smart phones on survey numbers (sample fields) chosen randomly. These photos and videos are uploaded on the site.

For 2016 kharif season, Tata AIG and Universal Sompo insurance agencies had won the bid and were authorized to provide crop insurance under KRSPMFBY in Karnataka with distribution of one cluster of 10 districts to Tata AIG and 2 clusters with 20 districts to Universal Sompo. And, 4331 insurance units were declared at hobli level and 8113 units were declared at gram panchayat level. Principal crops were declared at gram panchayat level while other crops were notified at hobli level. District agriculture department sends details to DES, which in turn will send consolidated details to state agriculture department, which issues notifications, calls for tender and finalises bid selecting insurance companies for providing crop insurance in the state for a particular agriculture season. Notifications are issued from Agriculture and Horticulture departments for respective crops. Although PMFBY specifies three levels of indemnity $(70 \%, 80 \%, 90 \%)$, considering the loss to farmers, government of Karnataka had fixed indemnity levels at $90 \%$ for irrigated crops and $80 \%$ for rainfed crops in KRSPMFBY.

Karnataka's experience with crop insurance coverage as said earlier has not been very satisfactory. If we look 
into the statistics on crop insurance furnished in table 1 for a period of 16 years (1999-2015), the coverage was below $10 \%$ both in terms of area and number of farmers insured. But the claim status was slightly better as it was $195 \%$ of gross premium collections. However, the situation seems to be improving with the introduction of KRSPMFBY as there is an increase in the number of farmers opting for crop insurance since 2016 under KRSPMFBY. There is also an increase in the area insured.

Table 1. Cumulative status of Crop insurance coverage

\begin{tabular}{cccccc}
\hline Details & $\begin{array}{c}\text { Farmers } \\
\text { Insured } \\
\text { (\%) }\end{array}$ & $\begin{array}{c}\text { Area In- } \\
\text { sured (\%) }\end{array}$ & $\begin{array}{c}\text { Share of } \\
\text { Claims in } \\
\text { Sum Insured } \\
\text { (\%) }\end{array}$ & $\begin{array}{c}\text { Share of } \\
\text { Claims to } \\
\text { Gross Premi- } \\
\text { um* (\%) }\end{array}$ & $\begin{array}{c}\text { \% of } \\
\text { Benefited } \\
\text { Farmers }\end{array}$ \\
\hline $\begin{array}{c}\text { India -1999- } \\
\text { 2015 (aver- } \\
\text { age) } \\
\text { Karnata- }\end{array}$ & 7.9 & 9.6 & 8.5 & 175.2 & 33.1 \\
$\begin{array}{c}\text { ka-1999-2015 } \\
\text { (average) }\end{array}$ & 6.5 & 6.6 & 9.4 & 195.4 & 39.2 \\
\hline
\end{tabular}

Source: Directorate of Economics and Statistics, State of Indian Agriculture 2015-16,MOA\&FW, Govt. of India ${ }^{[12]}$; Singh $2016^{[18]}$; *Premium+ Subsidy

As per 2010-11 agricultural census report, Karnataka state is having $1,21,61,457$ hectares of agriculture land and there are about 78,32,189 farmers. Out of which about $92.5 \%$ of farmers are small and marginal farmers in the state. Karnataka was in $8^{\text {th }}$ ranking among states in terms of crop insurance if we look into cumulative data for 15 years from 1999-2015.In the first year of the implementation of KRSPMFBY in kharif 2016, the Karnataka government notified 40 crops (27 food grains and oil seeds and13 annual, commercial and horticulture crops) for crop insurance. The crop insurance was purchased by $9,43,550$ farmers in kharif 2016 under KRSPMFBY.

The coverage of farmers under crop insurance schemes during kharif season across the districts of Karnataka from 2015 to 2018 is depicted in Figure 1. The share of farmers which was $11.3 \%$ under NAIS 2015 , increased to $12.2 \%$ in $2016,17.1 \%$ in 2017 going down to $15.6 \%$ in 2018. And there has been further decline to $14.1 \%$ in 2019 under KRSPMFBY during kharif season (not shown in figure -1). Among districts, the coverage of farmers has been higher in Dharwad, Bidar, Haveri, Gadag and Uttar Kannada districts and, lowest in Raichur, Bellary, Belagavi and Yadgir under both, NAIS and KRSPMFBY. In 2018, Koppal, Raichur, Bagalkot and Vijayapura showed increase in enrollment compared to previous years and the response was enormous with more than $50 \%$ of farmers enrolling for PMFBY in Dharwad, Bidar, Gadag and Haveri for 2018 kharif. More than $50 \%$ of the farmers have enrolled for crop insurance in Bidar, Gadag and Dharwad the highest being in Bidar (72.3\%) during 2018 kharif season. Overall, there was good response from farmers in 2017, but delayed payment for 2016 claims and many anomalies found in CCEs and assessment of claims resulted in lower enrolment thereafter.

In north Karnataka, the increase in coverage was from $20.4 \%$ under NAIS to $25 \%$ under KRSPMFBY. The increase in coverage was significant for rabi season also, which rose from $4.11 \%$ in 2015 (NAIS) to $15.1 \%$ in 2016 (KRSPMFBY). The coverage of farmers has been higher in north Karnataka region as compared to south Karnataka. For 2016 kharif crop the sum insured for food and oil crops per hectare of land in Karnataka varied from a minimum of Rs. 19,000 for horse gram to a maximum of Rs.51,000 for paddy in rainfed area and, from Rs.33,000 for soybean to Rs.82,000 for paddy in irrigated area. In the case of horticulture and commercial crops, the sum insured was minimum at Rs. 41,000 for rainfed cotton and maximum at Rs.1,34,000 for irrigated potato. The sum insured under RWBCIS for fruits was minimum for Sapota at Rs. 25,000 and highest for grapes at Rs. 5,00,000. In the case of vegetables, it was Rs. 37,500 for cauliflower and Rs.1,12,500 for chilly. And these rates varied between districts according to rainfed and irrigated conditions. While farmers' share in premium is fixed at $1.5 \%, 2 \%$ and $5 \%$ of sum insured for rabi, kharif (food and oil seeds) and annual / commercial / horticulture crops respectively, the actuarial premiums rates varied from $1.02 \%$ to $60.0 \%$ of sum insured for different crops under KRSPMFBY. And, the share of farmers in actuarial/gross premium paid to insurance companies in 2016 was $18.95 \%$ for crops under KRSPMFBY and $42.8 \%$ for crops under RWBCIS. This indicates that governments both centre and state together had to bear around $81 \%$ of the actuarial premium costs under KRSPMFBY and around 57\% of the insurance costs under RWBCIS.

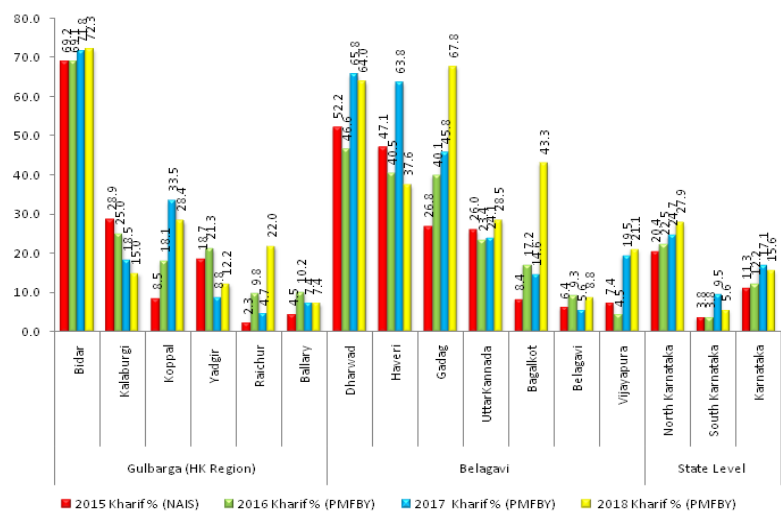

Figure 1. District-wise Coverage of Farmers under NAIS 2015, KRSPMFBY 2016, 2017, 2018 in north Karnataka during Kharif season (\%)

Source: Agriculture Insurance Corporation India (AIC), and Agriculture Department GOK. 
Table 2 shows that there has been an increase in the number of farmers being enrolled under crop insurance. The coverage has increased from 8.73 lakh farmers under NAIS in 2015 to 9.44 lakhs in 2016 and 13.33 lakh farmers under KRSPMFBY in 2017. Tremendous effort seems to have been made in Karnataka to enroll farmers in 2017 as the coverage of non-loanee farmers trebled (279\%) in 2017 kharif season and has remained more than loanee farmers in subsequent years.

Table 2. Coverage of farmers and Area insured [2015, 2016,2017, 2018, 2019]

\begin{tabular}{|c|c|c|c|c|c|}
\hline \multirow[b]{2}{*}{ Year } & \multicolumn{5}{|c|}{ Karnataka } \\
\hline & $\begin{array}{c}\text { Loanee } \\
\text { Farmers } \\
\text { (lakhs) }\end{array}$ & $\begin{array}{c}\text { Non- } \\
\text { Loanee } \\
\text { Farmers } \\
\text { (lakhs) }\end{array}$ & $\begin{array}{c}\text { Total in- } \\
\text { sured Farm- } \\
\text { ers (lakhs) }\end{array}$ & $\begin{array}{c}\text { Area } \\
\text { insured } \\
\text { (ha) }\end{array}$ & $\begin{array}{c}\text { Sum } \\
\text { Insured } \\
\text { (lakhs) }\end{array}$ \\
\hline $\begin{array}{l}2015 \text { Kharif } \\
\text { (NAIS) }\end{array}$ & 3.81 & 4.92 & 8.73 & 1216776 & 302678 \\
\hline $\begin{array}{c}2016 \text { Kharif } \\
\text { (KRSPMFBY) }\end{array}$ & 7.43 & 2.01 & 9.44 & 1203610 & 560953 \\
\hline $\begin{array}{c}2017 \text { Kharif } \\
\text { (KRSPMFBY) }\end{array}$ & 5.72 & 7.61 & 13.33 & 1803450 & 822345 \\
\hline $\begin{array}{c}2018 \text { Kharif } \\
\text { (KRSPMFBY) }\end{array}$ & 5.33 & 6.90 & 12.23 & 1452383 & 644296 \\
\hline \multirow[t]{2}{*}{$\begin{array}{c}2019 \text { Khar- } \\
\text { if(KRSPMF- } \\
\text { BY) }\end{array}$} & 4.87 & 6.15 & 11.02 & 1247412 & -NA- \\
\hline & \multicolumn{5}{|c|}{ North Karnataka } \\
\hline $\begin{array}{l}2015 \text { Kharif } \\
\text { (NAIS) }\end{array}$ & NA & NA & 7.2 & 1003661 & 235078 \\
\hline $\begin{array}{l}2016 \text { Kharif } \\
\text { (KRSPMFBY) }\end{array}$ & 6.42 & 1.38 & 7.8 & 1030668 & 474273 \\
\hline $\begin{array}{l}2017 \text { Kharif } \\
\text { (KRSPMFBY) }\end{array}$ & 4.79 & 4.01 & 8.8 & 1297411 & 590565 \\
\hline
\end{tabular}

Source: Agriculture Insurance Corporation India (AIC), and Agriculture Department, GOK

Around $5 \%$ of the non-loanee farmers were covered under crop insurance before implementation of KRSPMFBY $^{[19,20]}$ In 2015 (NAIS), 4.92 lakhs non-loanee farmers had insured for crop loss in kharif season. They constituted $56 \%$ of the total insured farmers. In 2016, their share in total enrollment went down to around $21 \%$. But, table 2 reveals that the share of non-loanee farmers in total enrollment improved (57\%) under KRSPMFBY during kharif 2017 , but has been going down thereafter indicating reduction in the tempo of the scheme may be due to several anomalies associated with the scheme.But, their coverage in crop insurance has remained higher than loanee farmers.

\section{Performance of NAIS-2015 Versus KRSPM- FBY - 2016}

Table 3 shows that a majority $(71 \%$ in NAIS and $72 \%$ in KRSPMFBY) of the farmers who purchased NAIS and
KRSPMFBY have benefited from crop insurance scheme in 2015 and 2016 respectively during kharif season in Karnataka. However, there is a slight decrease in the percentage of farmers benefited in north Karnataka, from $69 \%$ in 2015 to $65 \%$ in 2016 . Insurance claims were lesser in kharif 2016 in Kalaburgi, Vijayapura and Yadagir districts under KRSPMFBY due to good production of crop (especially tur).

Table 3. Performance of NAIS 2015 and KRSPMFBY2016 during Kharif season in Karnataka

\begin{tabular}{|c|c|c|c|}
\hline $\begin{array}{l}\text { Sl. } \\
\text { No. }\end{array}$ & Details & $\begin{array}{l}\text { NAIS } \\
\text { 2015-Kharif }\end{array}$ & $\begin{array}{c}\text { KRSPMFBY } 2016 \\
\text { - Kharif }\end{array}$ \\
\hline 1. & $\begin{array}{c}\text { Percentage of farmers benefit- } \\
\text { ed in Karnataka }\end{array}$ & $71 \%$ & $72 \%$ \\
\hline 2. & $\begin{array}{l}\text { Percentage of farmers benefit- } \\
\text { ed in North Karnataka }\end{array}$ & $68 \%$ & $65.3 \%$ \\
\hline 3. & $\begin{array}{l}\text { Area covered under Crop } \\
\text { Insurance Scheme }\end{array}$ & $\begin{array}{c}\text { Karnataka: } 10.0 \\
\% \\
\text { North Karnata- } \\
\text { ka: } 16.8 \%\end{array}$ & $\begin{array}{c}\text { Karnataka: } 9.9 \% \\
\text { North Karnataka: } \\
14.2 \%\end{array}$ \\
\hline 4. & $\begin{array}{l}\text { Share of Claims in Sum } \\
\text { Insured }(\%)\end{array}$ & $\begin{array}{c}\text { Karnataka } \\
23.2 \% \\
\text { North Karnata- } \\
\text { ka: } 24 \%\end{array}$ & $\begin{array}{c}\text { Karnataka: } \\
18.3 \% \text {, } \\
\text { North Karnataka: } \\
16.1 \%\end{array}$ \\
\hline 5. & $\begin{array}{c}\text { Average Claim Amount /Per } \\
\text { Hectare of area insured }\end{array}$ & $\begin{array}{l}\text { Average:Rs } \\
\quad 5770 \\
\text { North Karna- } \\
\text { taka:Rs } 5269\end{array}$ & $\begin{array}{c}\text { Average:Rs } 8535 \\
\text { North Karnataka: } \\
\text { Rs } 7509\end{array}$ \\
\hline 6. & $\begin{array}{c}\text { Share of Claims in Gross } \\
\text { Premium }\end{array}$ & Not Available & $\begin{array}{c}\text { Karnataka: } 130 \% \\
\text { North Karnataka: } \\
110 \%\end{array}$ \\
\hline
\end{tabular}

Source: Agriculture Insurance Corporation India (AIC) and Agriculture Department, Govt of Karnataka

District wise coverage of crop insurance revealsthat, around $10 \%$ of crop area was insured under both NAIS 2015 and KRSPMFBY 2016. The area insured was slightly higher (16.8\% under NAIS and $14.2 \%$ under KRSPMFBY) in north Karnataka than in south Karnataka. Insurance claim was $23.2 \%$ of the total sum insured amount under NAIS in Karnataka. However, the share of claim settlement in total sum insured declined from 23.2\% under NAIS 2015 to $18.3 \%$ under KRSPMFBY 2016 and was higher in districts like Bidar, Haveri, Dharwad, and Uttar Kannada and lower in Bagalkote, Bellary, Kalaburgi and Raichur. In 2016, claims under KRSPMFBY were higher than the gross premium by $130 \%$. The claims were higher than the gross premium in Bidar, Dharwad, Haveri, Uttar Kannada and Koppal districts and, lesser than farmers' premium in Bellary, Raichur, Kalaburgi and Vijayapura districts. The claim amount received by an insured farmer under KRSPMFBY 2016 on an average amounted to Rs.8535 per hectare (in the total area insured) in Karnataka, which is better than the amount received under NAIS 2015 (Rs.5770/ 
per hectare). The claim amount on an average is Rs.7509 per hectare in north Karnataka, which is lower than the average claim amount of Rs.15512per hectare in south Karnataka.

The enrolment and claim status for PMFBY and RWBIS together till March 2019 given in table 4 shows reduction in enrolment as compared to the enrollment in the first year of the two schemes in Karnataka. Delay in claim disbursement and lesser percentage of farmers benefited in 2017-2018 could be the reasons for lower response in 2018-19. Issues of multi-picking, rice versus paddy in claim assessment, default by farmers in stating crops for insurance and ignoring individual farmer's losses in much case were the reasons for delay in claim settlement. While the claims as percent to sum insured were higher in 2017 and 2019 it was less than $50 \%$ in 2018. Although there was delay in payment of claims, particularly for 2016 and 2017 kharif crop failure due to several disputes in claim assessment, the payment has been reported to be more than $98 \%$ for all the three years being $100 \%$ in $2017-18$. But, major part of these claims has been paid to farmers almost after more than one year of their assessment.

The share of initiated claims for PMFBY 2016 kharif season in sum insured was less than $20 \%$ during 2016 but, was 1.3 times (130\%) higher than the gross premium paid by farmers and state/central governments together and accounted for $95 \%$ of the gross premium collected for Universal Sompo and 196\% of the gross premium collected for TATA AIG insurance company.About $62 \%$ of farmers registered with Universal Sompo and around 89\% of those registered with Tata AIG were declared as beneficiaries.But, due to disputes in conducting CCEs, issues in estimating losses, yield challenges and due to bank related problems, only $75 \%$ of the claims initiated were paid by the two companies till January 2018. But, as said above, according to the information available from AIC the insurance companies had cleared more than $90 \%$ of the claims as of March 2020.

Table 5. Summary of Crop Insurance in Karnataka (2016 KRSPMFBY kharif)

\begin{tabular}{|c|c|c|}
\hline $\begin{array}{ll}\text { SI. } \\
\text { No. }\end{array}$ & Details & \\
\hline 1. & No of farmers covered & $9,43,550$ \\
\hline 2. & $\begin{array}{c}\text { Coverage of farmers (\% to total farm- } \\
\text { ers) }\end{array}$ & 12.21 \\
\hline 3. & No of applications/proposals & $10,42,000$ \\
\hline 4. & Loanee farmers $(\%)$ & 78.79 \\
\hline 5. & Non -loanee farmers $(\%)$ & 21.21 \\
\hline 6. & Area insured (Ha) & 1203610.12 \\
\hline 7. & Area insured per farmer (Ha) & 1.25 \\
\hline 8. & Average sum insured per hectare (Rs.) & 46605.88 \\
\hline 9. & Government Subsidy per hectare (Rs.) & 5318.90 \\
\hline 10. & Gross premium paid (Rs.) & 7898555788 \\
\hline 11. & Centre's share (Rs.) & 3200948790 \\
\hline 12. & State share (Rs.) & 3200948790 \\
\hline 13. & Farmers' share (Rs.) & 1496658208 \\
\hline 14. & $\begin{array}{l}\text { Farmers' share (premium to sum in- } \\
\text { sured) } \%\end{array}$ & 2.67 \\
\hline 15. & $\begin{array}{c}\text { Farmers' share in actuarial/gross premi- } \\
\text { um (\%) }\end{array}$ & 18.95 \\
\hline 16. & $\begin{array}{l}\text { Claims eligible for insurance ( } \% \text { of } \\
\text { applications) }\end{array}$ & 72.02 \\
\hline 17. & Claims initiated (Rs. in lakhs) & 102729.58 \\
\hline 18. & Share of claims in gross premium (\%) & 130.06 \\
\hline 19. & Share of claim in sum insured (\%) & 18.3 \\
\hline 20. & $\begin{array}{l}\text { Average premium paid per application } \\
\text { (Rs.) }\end{array}$ & 1436.33 \\
\hline 21. & $\begin{array}{l}\text { Average claim per eligible application } \\
\text { (Rs.) }\end{array}$ & 15040.95 \\
\hline 22. & $\begin{array}{l}\text { Claims paid (Rs. in lakhs) as of January } \\
2018\end{array}$ & $\begin{array}{c}76696.48 \\
\text { ( } 74.65 \% \text { of claims) }\end{array}$ \\
\hline 23. & $\begin{array}{l}\text { Pending claims as of January 2018* } \\
\text { (Rs. in lakhs) }\end{array}$ & $\begin{array}{c}26033.1 \\
\text { (33.94\% of beneficiaries) }\end{array}$ \\
\hline
\end{tabular}

Source: Agriculture Department, GoK

Note: *As per the information available from AIC, Rs. 5812.12 lakhs $(6 \%$ of the claims initiated), was the pending amount as of March 2020.

Table 4. Karnataka PMFBY \& RWBCIS Combined Crop Insurance Status (as on 31.08.2020)

\begin{tabular}{cccccccccc}
\hline & $\begin{array}{c}\text { Number of } \\
\text { Farmers Insured } \\
\text { (number in } \\
\text { Lakhs) }\end{array}$ & $\begin{array}{c}\text { Area } \\
\text { Insured (in } \\
\text { Lakh Ha.) }\end{array}$ & $\begin{array}{c}\text { Sum } \\
\text { Insured }\end{array}$ & $\begin{array}{c}\text { Farmers } \\
\text { Share in } \\
\text { Premium }\end{array}$ & $\begin{array}{c}\text { Gross } \\
\text { Premium }\end{array}$ & $\begin{array}{c}\text { Reported } \\
\text { Claims }\end{array}$ & $\begin{array}{c}\text { Paid } \\
\text { Claim }\end{array}$ & $\begin{array}{c}\text { Paid Claims } \\
\text { (as \% to } \\
\text { gross premi- } \\
\text { um) }\end{array}$ & $\begin{array}{c}\text { No. of Farmers } \\
\text { benefitted (num- } \\
\text { ber in Lakhs) }\end{array}$ \\
\hline $\mathbf{2 0 1 6 - 1 7}$ & 29.407 & 24.751 & $9,356.49$ & 234.796 & $1,343.48$ & $2,065.78$ & $2,061.07$ & 153.41 & $19.189(65 \%)$ \\
$\mathbf{2 0 1 7 - 1 8}$ & 21.409 & 18.053 & $8,718.51$ & 234.632 & $1,830.53$ & 858.18 & 858.18 & 46.88 & $6.187(28.9 \%)$ \\
$\mathbf{2 0 1 8 - 1 9}$ & 19.534 & 22.400 & $9,708.35$ & 273.318 & $1,859.16$ & $2,903.91$ & $2,846.7$ & 153.12 & $13.297(68 \%)$ \\
\hline
\end{tabular}

Source: https://pmfby.gov.in/stateWiseDataPage 
In the entire Karnataka, claims initiated under KRSPMFBY were highest for Haveri followed by Dharwad and Bidar districts. Vijayapura was in the last rank in terms of insured farmers as well claims initiated. Amount withheld due to bank related problems, multi picking issues, yield challenges was higher in Dharwad district. Uttar Kannada had higher amount withheld due to rice versus paddy issue in loss assessment.

\subsection{Observations from Farmers' Survey}

The level of awareness about the provisions of KRSPMFBY/RWBCIS/UPIS/CPIS was found to be very low among farmers. Only $48 \%$ of the farmers in the sample were aware of crop insurance schemes. Even the loanee farmers who were covered under insurance by banks and societies did not know about the premium amount, details of crops insured and the extent of area insured under crop insurance. In 2016, around $61 \%$ of the farmers in the sample had availed crop loan. Crop insurance was found to be higher among small farmers (34\%) and lowest $(17 \%)$ among the illiterate farmers. Sixty two percent of loanee and $2 \%$ of non-loanee farmers in the sample opted for crop insurance in 2016. However, the share of nonloanee farmers in the entire Karnataka is reported to be higher in 2017 kharif season. Their share in total enrollment improved from $21 \%$ in 2016 to $57 \%$ in 2017 . Totally, $38 \%$ of the farmers in the sample had insured their crops under KRSPMFBY in 2016 for kharif season their share being $58 \%$ in 2015 under NAIS. And, $4 \%$ of the insured farmers were tenants/sharecroppers. Crop loss was reported by $74 \%$ of the farmers in the sample for 2016 kharif season. While $7 \%$ of the insured farmers in the sample had received claims for 2015 kharif, none of the farmers in the sample villages received claims for 2016 kharif season except farmers in Mittimalakapur of Raichur district. Even these farmers reported that they were waiting for claims, which was withheld due to disputes (rice vs. paddy) in loss estimation between the state agriculture department and insurance companies. On an average $48 \%$ of the farmers in the sample also reported crop loss due to attack by wild animals at least once during the past 5 years from the day of the survey.

Only $29 \%$ of the insured farmers among the sample in Belgavi district had opted for UPIS under KRSPMFBY in 2016 kharif season. Majority of the farmers were unaware of UPIS and some of those who knew about the scheme could not enroll for personal accident and life insurance due to the age limit of 70 and 50 years fixed respectively for enrolling under these two schemes. Around $57 \%$ of the farmers felt that the scheme is beneficial to them. Since UPIS is clubbed under KRSPMFBY, separate details of coverage were not available for Belgavi district where it is implemented on pilot basis.

Around $73 \%$ of the farmers felt the need for improving existing crop insurance schemes, particularly KRSPMFBY. But they strongly feel that crop insurance is necessary to farmers and said that even the irrigated areas may need crop insurance in future with wide variations in climate experienced by them in recent years

\subsection{Stakeholder Perceptions from the Regional Workshops}

A majority of the farmers and other stakeholders like bankers, agriculture, revenue and insurance officials who participated in stakeholder workshops held in Dharwad, Vijayapura, Belgaum, Haveri, Kalaburgi and Raichur realize the need for crop insurance and opine KRSPMFBY to be a good scheme. But, farmers faced difficulties in implementation of the scheme. To avail PMFBY crop insurance in 2016 for kharif, they had to shuffle between banks, agriculture department and insurance companies for clarifications about crop insurance as some of the officials were unaware of the procedural issues. Paddy growers in Uttar Kannada were not interested in crop insurance as they anyway get around $60 \%-70 \%$ yield and, loss above this is not met by crop insurance as per the existing formula. Farmers were concerned about non-inclusion of other minor crops in claims despite of crop loss. Although they had insured for multiple crops and paid the premiums accordingly, they found insurance claims being settled for only one crop in some taluks. Since term sheets were not made available to all the farmers, they were unable to know the extent of coverage of loss and the terms and conditions. Delayed CCE was also a cause of concern among farmers whose fields were selected for $\mathrm{CCE}$ as farmers had to wait for the harvest till CCE was completed by officials or field workers. Farmers assume anomalies in fixing threshold yield and therefore recommended district-wise scientific assessment of "potential yield" in fixing threshold yield. In addition, "interest on claim amount for delayed settlement", "fixing deadline for disbursement of claims", extending crop insurance to all crops including "sugarcane", payment of "No claim bonus", "automatic reinsurance of policies" every year, establishing "Crop Insurance Corporation of India" or Reviving Agriculture Insurance Company of India, Ltd and extending "free crop insurance to farmers run by government agency" were some of the main recommendations made by farmers in regional workshops. Farmers felt that tendering of crop insurance would leave them in the hands of commercial interests or multi-national companies.

Like farmers, bankers also raised their voice in the 
workshop saying that banks were unable to meet the requirements of crop insurance registration in time due to delays in notification by agriculture department, limited staff in banks, interruptions in internet connections, human errors due to dead line pressure leading to duplicate entries / mis-entry of account numbers, changes in the names of farmers as against that in Aadhar, survey numbers, village name, mismatch of IFSC codes, branch name, mobile numbers, etc. Bankers said that they cannot inspect every field to validate crops, which needs to be confirmed through Raita Sampark Kendras, gram panchayats and agriculture extension officials. Farmers continue to default by growing crops other than insured and therefore cannot claim insurance many a times. However, this problem seems to be resolved with recent changes made in PMFBY guidelines which makes insurance voluntary for loanee farmers, hence avoiding default in listing crops. Not maintaining seasonality discipline by agriculture department was stated to be one of the main causes for low coverage of farmers under crop insurance.

The discussions at regional workshops helped researchers in understanding the gamut of crop insurance problems particularly at the implementation stage. It was found that delinking crop loan with crop insurance may reduce default by farmers on crop changes and increase coverage under the schemes. To reduce the anomalies in registration and avoid confusion among farmers, mandatory issuance of receipt/acknowledgment by banks to farmers for premium payment was found to be the way out. Stakeholders felt that the Agriculture department should organise bidding once in a year both for kharif and rabi seasons (may be in April) together to reduce delay in notifications. The Central government has already approved tendering of crop insurance for three years period. Involving agriculture university graduates in CCEs, quick settlement of claims within 3 months of yield estimation, social auditing of crop insurance schemes, enhancement of compensation on crop loss due to attack by wild animals, redressal of grievances at district level under the leadership of District Commissioner were some of the suggestions made to make crop insurance reach all the farmers in the state.

\subsection{Beyond Crop Insurance}

Crop insurance cannot be a single solution to mitigate risks of agriculture production. It is one of the measures and needs to be supplemented by other measures. There is a need to go beyond crop insurance and look into the measures that can strengthen and sustain agriculture production. Some of the measures that can result in ease of doing agriculture are promoting Agri ponds to increase the capacity of agriculture land, practical implementation of Minimum Support Prices (MSP), ensuring proper marketing through farmers' organizations, increasing returns through organic farming and fair prices following best practices. During the survey, which was a drought year, sowing and greenery was noticed around Agri ponds in villages, while fields at distance lay barren during agriculture season. So, investing on Agri ponds could yield better returns and help farmers to sustain agriculture even in times of drought.

\section{Conclusions}

In sum, the study finds the necessity of crop insurance to farmers in the background of adverse weather conditions prevailing in the state. Information gathered through discussions in regional workshops held across selected districts of north Karnataka revealed that there was a positive response to PMFBY in Karnataka in initial years and the scheme created greater awareness about crop insurance among farmers. Despite issues in claims and yield estimates, majority of the farmers feel that crop insurance is essential to farmers. The coverage of farmers under crop insurance in Karnataka increased from $11.3 \%$ in 2015 (NAIS) kharif to $12.2 \%$ in 2016 and $17.0 \%$ in 2017 (KRSPMFBY) for kharif season and, the increase was from $20.4 \%$ (under NAIS) to $25 \%$ under KRSPMFBY for north Karnataka. The increase in coverage was significant for rabi season also, which rose from $4.11 \%$ in 2015 (NAIS) to $15.1 \%$ in 2016 (KRSPMFBY).

Insured area has increased from 10\% under NAIS 2015 to $14.8 \%$ under KRSPMFBY 2017 during kharif season. Officials feel that KRSPMFBY has increased transparency through digitalization of the whole process, which according to them will reduce the anomalies to the minimum in the coming years. Some of the difficulties faced in registration of farmers are being corrected with the joint efforts of NIC, banks, insurance agencies and agriculture department.

PMFBY has many provisions to make farmers happy and secured if implemented in accordance with the guidelines following seasonality disciplines and sound CCEs. A few of the anomalies that existed are being cleared out after concerns were expressed from states and farmer representatives. A few more changes are expected to be inserted in the coming days by the central government ${ }^{\mathbb{D}}$. The combined claims for PMFBY and RWBIS were higher than the gross premium collected in states like Tamil Nadu, Karnataka, Kerala and Andhra Pradesh. Tamil Nadu has been getting higher paid claims

(1) The Economic Times, "Govt approves changes in PMFBY to make it optional for farmers", February 19, 2020. 
every year being 3.3 times in 2016-17 and 1.5 times of gross premium in 2018-19. Andhra Pradesh and Chhattisgarh farmers were better compensated in 2018-19. But paid claims as percentage of gross premium were very low for all the three years from 2016 to 2019 in Bihar, Gujarat, Maharashtra and Uttar Pradesh. This could be the reason why Bihar has opted out from PMFBY in 2018. Many other states may fall out of PMFBY if there is no improvement in its implementation. The paid claims as share of gross premiums combined for PMFBY and RWBCIS were $77 \%$ in $2016-17,89 \%$ in $2017-18$ and $91 \%$ in $2018-19$ for the country ${ }^{\mathbb{D}}$. If one separates claims of PMFBY from RWBCIS, they are reported to be much lower than the gross premium for all states together. It should always be clear among beneficiaries that insurance is for risk coverage. Normal years and non-claims enable insurance agencies to make payment in risky years and towards claims in affected areas. Only then insurance agency can participate and survive in insurance market and that is how insurance sector can benefit the needy. Everyone who pays premium cannot expect immediate benefit. Some of the private insurance companies have opted out of crop insurance due to high insurance claims and loss. While Punjab did not opt for PMFBY, states like West Bengal, Andhra Pradesh have given up PMFBY and, Jharkhand started its own crop insurance. Maintaining seasonal discipline is edifice of a sound crop system. Violation of this has been a major hurdle in popularizing crop insurance in India. Even earlier schemes had huge pending claims years after claim reporting. As per the Report of the CAG of India ${ }^{[1]}$, the quantum of pending claims as ratio of reported claims in 2017 for India was Rs. 7010 crores under NAIS, Rs. 332 crores under MNAIS and Rs. 999 crores under WBAIS from kharif 2011 to rabi 2015-16. In Karnataka, pending claims from kharif 2016 to rabi/summer 201819 amount to 311.9 crores under KRSPMFBY ${ }^{2}$. This makes farmers impatient and averse to crop insurance as they lose faith and do not have money in hand to meet the expenses including premium payment for the next crop season. Therefore, it is necessary to take farmers in to confidence by making timely claim payment and strictly follow seasonality discipline. And the need of the hour is to create awareness among farmers and create cordial relations between farmers and insurance agencies through celebration of "Crop insurance day or Mela" every year before sowing season. Farmers are not happy with loss assessment. Every year there are issues in as-

(1) https://pmfby.gov.in/stateWiseDataPage

(2) Agriculture Insurance Corporation India (AIC) sessment and therefore delays in claim settlement. There should be clarity and consensus between the agriculture department and insurance agencies on loss assessment. While the issue of paddy versus rice has been resolved in fixing threshold yield and claims, the issue of multi picking for crops like chilly, tomato and cotton needs to be clarified and fixed. And, farmers' request for considering "No claim bonus", setting up of district level "Grievance redressal cell", weather stations, considering individual heavy losses in rare cases with evidence, correcting differences in fixing threshold yield, "automatic reinsurance of policies" every year unless intimated by farmer for changes and payment of interest on delayed claims should be considered for smooth and large scale implementation of PMFBY in India.

\section{References}

[1] CAG. Report of the Comptroller and Auditor General of India on Performance of Agriculture Crop Insurance Schemes. Report No.7 of 2017, Ministry of Agriculture and Farmers' Welfare, Union Government (Civil), New Delhi, 2017. Available at: www.cag.gov.in/.../report-no7-2017-performanc

[2] Ifft Jennifer. Government Vs Weather: The True Story of Crop Insurance in India. Research Internship Papers 2001, Centre of Civil Society, New Delhi, 2001.

http://www.ccsindia.org/

[3] Manojkumar K., Sreekumar B. Ajithkumar G. S. Crop Insurance Scheme: A case study of banana farmers in Wayanad district. Discussion Paper No. 54, Kerala Research Programme on Local Level Development, Thiruvananthapuram, 2003.

[4] Nair Reshmy. Crop Insurance in India: Changes and Challenges. Economic and Political Weekly, 2010, 45(6): 19-22.

[5] Ravi Kumar. Crop insurance - tribulations and Prospects of farmers with reference to Nuzvid, Krishna district. International Journal of Marketing, Financial Services \& Management Research, 2013, 2(9): 171181

[6] Government of India. Report of Joint Group on Crop Insurance, Ministry of Agriculture, Department of Agriculture and Cooperation, Government of India, New Delhi, 2004.

[7] Banerjee D., Bhattacharya U. Innovations in Agricultural Insurance in India: Retrospect and Prospect. Indian Journal of Agricultural Economics, 2011, 66(3): 457-71.

[8] Swain Mamata. Crop Insurance for Adaptation to Climate Change in India. Asia Research Centre 
working paper 61, London School of Economics and Political Science, London United Kingdom, 2014.

[9] Department of Agriculture \& Cooperation. Report of the Committee to Review the Implementation of Crop Insurance Schemes in India. Ministry of Agriculture, Government of India, New Delhi, 2014.

[10] CSE. Pradhan Mantri Fasal Bima Yojana: An Assessment. Centre for Science and Environment, New Delhi, 2017.

[11] Dey and Maitra. Agriculture insurance in India: Promise, pitfalls, and the way forward, Economic and political weekly, 2017, 52(52): 88-96.

[12] Directorate of Economics and Statistics. Agriculture Statistics at a Glance. Ministry of Agriculture and Farmers Welfare, Government of India, New Delhi, 2016.

[13] Kalavakonda V., Mahul O. Crop insurance in Karnataka. World Bank Policy Research Working Paper No 3654, World Bank, Washington, D.C, 2005.

[14] Rajeev, Meenakshi, Bhattacharjee, M., Vani, B P. Crop Insurance and Risk Mitigation: Experiences from India. ICDD Working Paper No. 15. University of Kassel, Germany, 2015.

[15] NSSO. Situation Assessment Survey of Farmers. 59th Round, January 2003-December 2003 National Sample Survey Office, Ministry of Statistics and Programme Implementation, Government of India, 2003.

[16] ICFA. ICFA Report on Crop Insurance in India. Indian Council of Food and Agriculture, New Delhi, 2016.

[17] Goudappa S.B., Reddy B. S., Chandrashekhar S.M. Farmers Perception and Awareness about Crop Insurance in Karnataka, Indian Research Journal of Extension Education, 2012, Special Issue(2): 218-222.

[18] Singh Archana. Agriculture Insurance in India. Bimaquest, 2016, 16(2): 69-95.

[19] Vyas V., Singh, S. Crop insurance in India: Scope for improvement. Economic and Political Weekly, 2006, 41(43/44): 4585-4594.

[20] Indian Express. PM crop insurance sees more coverage of non-loanee farmers. July 24, 2017. 